\title{
EFFECT OF AUTONOMIC BLOCKING AGENTS ON THE CARDIOVASCULAR EFFECTS OF OCTAPRESSIN IN THE RAT
}

\author{
Wybren DE JONG and Stuart M. MCLEOD * \\ Department of Pharmacology, Medical Faculty, University of Utrecht, \\ Vondellaan 6, Utrecht, The Netherlands \\ Accepted 18 January 1967
}

Wybren DE JONG and Stuart M. McLEOD, Effect of autonomic blocking agents on the cardiovascular effects of Octapressin in the rat, European J. Pharmacol. 1 (1967) 93-98.

Cardiovascular effects of Octapressin were studied in anesthetized male albino rats. The effect of pretreatment with the following blocking agents was evaluated: atropine, phenoxybenzamine, propranolol, hexamethonium and chlorpromazine. A decrease in blood pressure and in heart rate was induced by phenoxybenzamine; propranolol treatment caused a decrease in heart rate and an increase in circulation time.

Injections of 2,6 and $18 \mathrm{mU}$ Octapressin caused no changes in cardiac output or in central venous pressure. The increase in blood pressure following Octapressin was found to be dose-dependent in the saline-treated controls as well as in the rats pretreated with the autonomic blocking agents. The pressor response to Octapressin was increased by atropine, phenoxybenzamine, propranolol and chlorpromazine.

From these data it is concluded that the increase in blood pressure following Octapressin is caused by an increase in vascular resistance in the systemic circulation.

\author{
Cardiovascular effects of Octapressin \\ Blood pressure \\ Heart rate \\ Cardiac output
}

\author{
Circulation time \\ Autonomic blocking agents \\ Atropine \\ Phenoxybenzamine
}

Propranolol

Hexamethonium

Chlorpromazine

\section{INTRODUCTION}

The increment of arterial blood pressure (BP) induced by vasopressin depends, for a major part, on an increase in the vascular resistance of the systemic circulation (Wagner and Braunwald, 1956; Page and Olmsted, 1963; Maxwell, 1965). The contribution of cardiac output (CO) to the rise in BP is less clear, as a decrease in CO (Longo et al., 1964; Maxwell, 1965), an increase in CO (Beznak, 1959) and no change in CO (Wagner and Braunwald, 1956; Tsakiris et al., 1964) have been reported.

For this reason the effects of a synthetic vasopressin $\left(\right.$ phe $^{2}$-lys ${ }^{8}$-vasopressin, Octapressin: Boissonnas and Guttmann, 1960; Berde et al., 1961) on CO and on BP were determined in the anesthetized rat. To avoid moderator reflexes, which are known to occur in the intact animal (Heymans and Neil, 1958; Page and McCubbin, 1965) and which presumably obscure direct actions on cardiac function (Page and Olmsted,

\footnotetext{
* Present address:: Department of Pharmacology, University of Toronto, Toronto 5, Canada.
}

1963; Rosas et al., 1965), the effect of the peptide was also studied in rats treated with autonomic blocking agents.

\section{METHODS}

\subsection{General}

Male albino rats (190-320 g) were used. Half an hour before urethane anesthesia $(1.0-1.5 \mathrm{~g} / \mathrm{kg}$, i.p.), the animals of four of the experimental groups were respectively injected s.c. with one of the following blocking agents: atropine sulfate, phenoxybenzamine (dibenzyline, Smith, Kline and French), propranolol (inderal, I.C.I.), hexamethonium chloride, each in a dose of $10 \mathrm{mg} / \mathrm{kg}$. One group of rats was anesthetized with pentobarbital sodium (Nembutal, Abbott, $35 \mathrm{mg} / \mathrm{kg}$ i.p.). These rats had been injected s.c. 14 hours before with chlorpromazine hydrochloride (Largactil, Specia, $50 \mathrm{mg} / \mathrm{kg}$ ). Doses are expressed in terms of the salt used. Saline served as the placebo for the control group of animals. Thus, 6 groups of differently treated rats were obtained. 
To maintain near normal body temperature during the experiment, the animals were kept in a box having an ambient temperature of $29-31^{\circ} \mathrm{C}$.

\subsection{Experimental procedure}

The rats in each group of 6, treated as described above, were used in random order; in total 48 animals were studied. Injections of Octapressin (2, 6 and $18 \mathrm{mU})$ and of saline $(0.10$ $\mathrm{ml}$ ) were given via a lateral tail vein, and washed in with $0.05 \mathrm{ml}$ saline. Doses were given per animal since, in previous experiments, we found pressor response to Octapressin independent of body weight in male rats of $160-300 \mathrm{~g}$. A randomly selected dose was given every $30 \mathrm{~min}$. During the control period ( $\pm 15 \mathrm{~min}$ ) preceding the injection of the first dose, $3 \mathrm{CO}$, heart rate (HR) and circulation time (CT) determinations were made. The following 3 doses were each preceded by one $\mathrm{CO}$, one HR and one CT determination.

\section{3. $B P$ and HR measurement}

BP was monitored from a femoral artery, using a Statham (P $23 \mathrm{AC}$ ) transducer and a Grass polygraph (model 5D); HR was calculated from the BP recording. Pressor responses were calculated as the increase in diastolic BP plus $\frac{2}{5}$ pulse pressure at peak of pressor response. Thus calculated, the pressor response correlated well with the increase in electrically determined mean pressure.

\subsection{CO and CT measurement}

$\mathrm{CO}$ was determined by a modification of the thermodilution method described by Richardson et al. (1962). A thermistor (Philips B8-320-02 $\mathrm{P} / 470 \mathrm{~K}$ ), at the tip of a polyethylene cannula, was inserted through the left carotid artery into the aorta. The position of the thermistor was later checked by autopsy. The response time of the thermistor and the recorder was $0.2 \mathrm{sec}$. The time required to respond to $67 \%$ of the total temperature change in moving the thermistor from air at room temperature to a saline solution of $4^{\circ} \mathrm{C}$ cooler was measured as response time.

For each $\mathrm{CO}$ determination $0.12 \mathrm{ml}$ of saline of $28.4^{\circ} \mathrm{C}$ was quickly injected via a jugular vein. Body temperature of the rats during the measurements was calculated from the resistance of the thermistor. The BP and the thermodilution curves were recorded on the Grass polygraph. The area under the thermodilution curve was determined by planimetry after correction for recirculation by semilogarithmic extrapolation and replotting. $\mathrm{CO}$ was calculated with the modified Stewart-Hamilton equation according to Fegler (1957). The time between onset of the thermodilution curve and the onset of recirculation was calculated as CT. The CO curves and the HR's were recorded at the peak of the pressor response, which occurred at $\frac{1}{2}-1 \frac{1}{2} \mathrm{~min}$ following Octapressin injections.

\subsection{Central venous pressure measurement}

In preliminary experiments the effect of 2,6 and $18 \mathrm{mU}$ Octapressin on central venous pressure (CVP) was studied in the 6 groups of pretreated rats (6 rats per group). A cannula was located in the superior vena cava and connected to a Statham transducer (P $23 \mathrm{BC}$ ); the CVP was recorded on the Grass polygraph. In this way, changes in CVP of more than $0.1 \mathrm{~mm} \mathrm{Hg}$ could be detected. A mean CVP of $0.4 \pm 0.5 \mathrm{~mm} \mathrm{Hg}$ ( \pm S.E.) was recorded in the control group. Neither the pretreatment with the blocking agents nor the injections of Octapressin into the 6 groups of differently treated rats affected CVP significantly. For this reason no further CVP measurements were done in this study.

\subsection{Statistics}

Results are expressed as mean \pm standard error of the mean (S.E.). Statistical analysis of the data was performed using Wilcoxon's two sample test (Wilcoxon, 1945).

Table 1

Effect of blocking agents on cardiovascular parameters during control period.

\begin{tabular}{|l|c|c|c|c|}
\hline \multicolumn{1}{|c|}{ Treatment } & $\begin{array}{c}\text { Blood pressure } \\
\text { (mm Hg) }\end{array}$ & $\begin{array}{c}\text { Cardiac output } \\
\text { (ml/min/100 g) }\end{array}$ & $\begin{array}{c}\text { Heart rate } \\
\text { (beats/min) }\end{array}$ & $\begin{array}{c}\text { Circulation time } \\
\text { (sec) }\end{array}$ \\
\hline Saline & $108 \pm 8$ & $29 \pm 3$ & $\mathbf{4 2 1} \pm 10$ & $4.4 \pm 0.2$ \\
Atropine & $99 \pm 8$ & $32 \pm 5$ & $\mathbf{4 2 4} \pm 11$ & $4.1 \pm 0.2$ \\
Phenoxybenzamine & $49 \pm 6$ & $36 \pm 5$ & $\mathbf{3 6 8} \pm 20$ & $3.8 \pm 0.2$ \\
Propranolol & $93 \pm 9$ & $25 \pm 3$ & $291 \pm 19$ & $5.7 \pm 0.5$ \\
Hexamethonium & $108 \pm 10$ & $35 \pm 6$ & $400 \pm 16$ & $4.3 \pm 0.1$ \\
Chlorpromazine & $98 \pm 7$ & $29 \pm 7$ & $\mathbf{4 0 9 \pm 1 7}$ & $4.4 \pm 0.2$ \\
\hline
\end{tabular}




\section{RESULTS}

The effects of the treatment with the blocking agents on the respective cardiovascular parameters as measured during the control period preceding the administration of Octapressin are shown in table 1. A pronounced decrease in BP was observed in the phenoxybenzamine-treated group $(p<0.01)$, and $\mathrm{CO}$ of these animals showed a slight increase. Thus, phenoxybenzamine caused a decrease in vascular resistance to approximately $36 \%$ of the control value. Treatment with phenoxybenzamine and propranolol caused a decrease in HR (respectively, $p<0.05$ and $p<0.01)$. Propranolol also caused an increase in CT $(p<0.05)$.

The effect of Octapressin on BP is depicted in fig. 1. Saline injections had no significant effect on BP. Similar dose-response curves were found in the saline-treated control group and in the group treated with hexamethonium. In the 6 and $18 \mathrm{mU}$ dose-range, a potentiation of Octapressin-induced increase of $\mathrm{BP}$ was noted in animals treated with phenoxybenzamine, chlorpromazine and atropine. Chlorpromazine also augmented the effect of $2 \mathrm{mU}$ Octapressin, while propranolol increased the effect of $18 \mathrm{mU}$ Octapressin only.

The effects of $18 \mathrm{mU}$ Octapressin on $\mathrm{CO}, \mathrm{HR}$ and $\mathrm{CT}$ are shown in table 2 . Injections of saline and the lower doses of Octapressin caused no significant changes in these parameters. $\mathrm{CO}$ and CT were not significantly affected by $18 \mathrm{mU} \mathrm{Oc-}$ tapressin. When compared to the effect of saline injection, a significant $(p<0.05)$ decrease in HR was found following the administration of $18 \mathrm{mU}$ Octapressin in the control group. A similar decrease in HR was observed in the rats treated with atropine, hexamethonium and chlorpromazine. A minimal decrease in HR occurred in the rats treated with phenoxybenzamine and propranolol. The decrease in HR of the propranololtreated rats was significantly $(p<0.05)$ less than the observed decrease in the saline-treated controls.

BP recordings showed no signs of cardiac irregularities following Octapressin injections.

\section{DISCUSSION}

The present experiments show a dose-related increase in BP following the injection of Octapressin, which is not accompanied by significant changes in $\mathrm{CO}$ and $\mathrm{CT}$ in intact, anesthetized rats and in anesthetized rats treated with autonomic blocking agents. Minor decreases in HR were found following administration of the highest dose of Octapressin $(18 \mathrm{mU})$. Thus, the BPresponse to Octapressin apparently is caused by

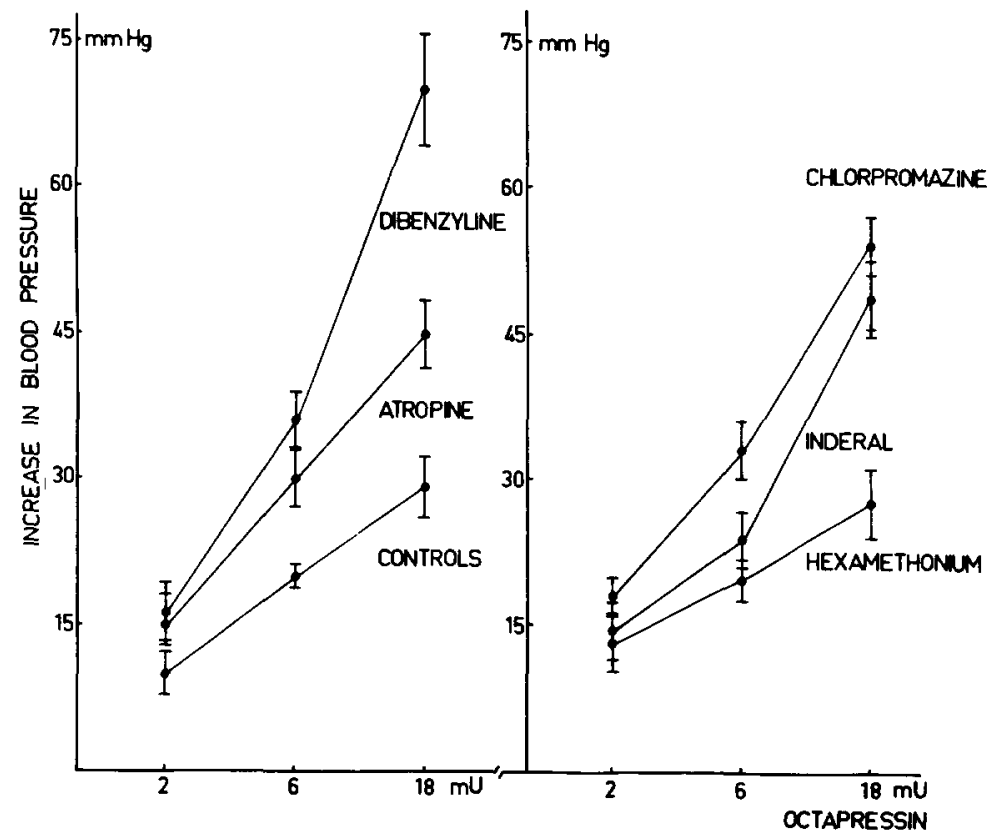

Fig. 1. Effect of Octapressin on blood pressure. Eight rats in each group. 
Table 2

Effect of $18 \mathrm{mU}$ Octapressin on heart rate, blood pressure, cardiac output and circulation time of the rat.

\begin{tabular}{|c|c|c|c|c|c|}
\hline \multirow[b]{2}{*}{ Treatment } & \multicolumn{2}{|c|}{$\begin{array}{l}\text { Change in heart rate } \\
\text { (beats } / \mathrm{min} \text { ) }\end{array}$} & \multirow{2}{*}{$\begin{array}{c}\begin{array}{c}\text { Increase in } \\
\text { blood pressure } \\
\text { (mm Hg) }\end{array} \\
18 \text { mU Octa- } \\
\text { pressin }\end{array}$} & \multirow{2}{*}{$\begin{array}{c}\begin{array}{c}\text { Change in } \\
\text { cardiac output } \\
(\mathrm{ml} / \mathrm{min} / 100 \mathrm{~g})\end{array} \\
18 \text { mU Octa- } \\
\text { pressin }\end{array}$} & \multirow{2}{*}{$\begin{array}{c}\begin{array}{c}\text { Change in } \\
\text { circulation time } \\
\text { (sec) }\end{array} \\
\begin{array}{c}18 \text { mU Octa- } \\
\text { pressin }\end{array}\end{array}$} \\
\hline & Saline & $\begin{array}{l}18 \text { mU Octa- } \\
\text { pressin }\end{array}$ & & & \\
\hline $\begin{array}{l}\text { Saline } \\
\text { Atropine } \\
\text { Phenoxybenzamine } \\
\text { Propranolol } \\
\text { Hexamethonium } \\
\text { Chlorpromazine }\end{array}$ & $\begin{array}{l}+3 \pm 3 \\
+1 \pm 1 \\
-1 \pm 2 \\
+6 \pm 1 \\
+4 \pm 3 \\
+5 \pm 2\end{array}$ & $\begin{aligned}-17 & \pm 6 \\
-23 & \pm 9 \\
-3 & \pm 8 \\
-2 & \pm 2 \\
-18 & \pm 12 \\
-40 & \pm 21\end{aligned}$ & $\begin{array}{l}29 \pm 3 \\
43 \pm 4 \\
70 \pm 6 \\
47 \pm 4 \\
28 \pm 3 \\
54 \pm 3\end{array}$ & $\begin{array}{r}+3.0 \pm 2.4 \\
+1.3 \pm 2.9 \\
-4.2 \pm 2.5 \\
0.0 \pm 1.9 \\
-2.0 \pm 3.6 \\
-1.6 \pm 1.8\end{array}$ & $\begin{array}{r}0.0 \pm 0.2 \\
+0.2 \pm 0.2 \\
+0.1 \pm 0.1 \\
0.0 \pm 0.3 \\
-0.1 \pm 0.4 \\
+0.3 \pm 0.5\end{array}$ \\
\hline
\end{tabular}

an increase in the vascular resistance of the systemic circulation. This is in agreement with previous studies with vasopressins reported by Wagner and Braunwald (1956) and Feruglio et al. (1964).

Part of the literature on $\mathrm{CO}$ with vasopressin and Octapressin however is at variance. A decline in $\mathrm{CO}$ following Octapressin has been observed by different investigators (Ribot et al., 1963; Segel, 1964; Longo et al., 1964 and Maxwell, 1965), while Wakim et al. (1954) reported a decrease in $\mathrm{CO}$ following vasopressin (pitressin). In patients, Wagner and Braunwald (1956) failed to find an effect of vasopressin (pitressin), and Feruglio et al. (1964) and Tsakiris et al. (1964) observed no effect of Octapressin on CO. Goldman (1966) who studied the effect of vasopressin (pitressin) infusion in the unanesthetized rat found no significant change in $\mathrm{CO}$ at a dose of $30 \mathrm{mU} / \mathrm{kg} / \mathrm{min}$, but at a dose of $90 \mathrm{mU} / \mathrm{kg} / \mathrm{min}$ CO decreased to $50 \%$ of the control value. Beznák (1959) reported that infusion of a high dose of vasopressin (pitressin) caused an increase of $\mathrm{CO}$ in the hypophysectomized rat and in the intact rat, while a lower dose decreased $\mathrm{CO}$ in the hypophysectomized rat and had no effect on $\mathrm{CO}$ in the intact rat. The increase of $\mathrm{CO}$ as reported by Bollobás (1963) in cats receiving Octapressin, is of questionable significance since this was concluded from pulse pressure changes only.

Species and strain differences (Nielsen, 1965), the source of vasopressin (Crawford, 1965), the kind of anesthesia, the mode of administration and the dose used may explain the discrepancies in reported action of vasopressins on cardiovascular function. The relative low doses of the peptide used in the present study may explain the absence of changes in CO.

An increased pressor response to Octapressin occurred in the rats treated with atropine, phenoxybenzamine, propranolol and chlorpromazine. Surprisingly, hexamethonium did not have such an effect on the pressor response. This may be due to ineffective treatment, since no significant decrease of BP was observed. We recently observed (unpublished data) that the hexamethonium treatment completely blocked the pressor response to $20 \mu \mathrm{g}$ of the sympathetic ganglionic stimulating agent 1.1-dimethyl-4phenyl-piperazinium iodide (DMPP), while in control animals an increase in BP of $56 \pm 3.7$ $\mathrm{mm} \mathrm{Hg} \mathrm{( \pm} \mathrm{S.E.)} \mathrm{was} \mathrm{found.} \mathrm{Page} \mathrm{and} \mathrm{Taylor}$ (1950) and Nash (1965) reported that effective ganglionic blockade in anesthetized dogs with respectively, tetraethylammonium and chlorisondamine also failed to augment the pressor response to vasopressin. These findings demonstrate the absence of a direct correlation between ganglionic blockade and augmentation of pressor responses as observed previously (Haas and Goldblatt, 1959; Page and McCubbin, 1959).

In his original contribution to the understanding of the regulation of normotensive BP and the pathogenesis of arterial hypertension, Page (1949). proposed his "mosaic theory", stating that "even the simplest hypertension is a mosaic in which many mechanisms are to a greater or lesser extent involved". This theory describes the circulation in terms of an equilibrated system in which the various components controlling tissue perfusion act in concert to maintain adequate perfusion under varying demands (quoted: Page and Olmsted, 1963). Later studies (Page and McCubbin, 1959, 1963, 1965; Haas and Goldblatt, 1959; Page and Olmsted, 1963) revealed a similar kind of complex mechanism for the regulation of $\mathrm{BP}$ responses to vasoactive agents. In the unanesthetized dog, an interplay of a spontaneously variable $\mathrm{CO}$ and peripheral resistance results in a relatively constant basal BP (Page 
and Olmsted, 1963). Variability of vascular responsiveness depends mainly on an intact nervous system, since it can be abolished by cervical section of the spinal cord (Page and McCubbin, 1963). It is likely that the use of urethane and pentobarbital anesthesia in our experiments caused considerable inhibition of the central nervous system, and thus may have modified cardiovascular responsiveness.

From their experiments, Page and McCubbin (1963) suggested that at least four mechanisms may play a role in the increased pressor response to vasoactive agents following the administration of ganglioplegics to unanesthetized dogs. Elimination of parasympathetic and of sympathetic reflexes, the blocking of $\beta$-vasodilator receptors and a direct sensitizing effect of ganglionic blocking agents on blood vessels. Our data and observations reported in the literature substantiate this hypothesis. Adrenergic blockade caused an increased pressor response to vasopressin as observed by Dekanski (1952), who proposed the use of phenoxybenzaminetreated rats as a sensitive and reliable preparation for the assay of vasopressin. Gardier et al. (1965) and Page and McCubbin (1965) described an augmented pressor response to vasopressin following atropine. The phenoxybenzamine-induced increase in the pressor response may be explained in part by the parasympathetic blocking effect of phenoxybenzamine (Romano and Hinshaw, 1965).

Peripheral BP sensitizing effects of ganglioplegics were observed by Shimamoto et al. (1955); Mantegazza et al. (1958); Prado and Carlini (1959); Lum and Rashleigh (1961); and Page and McCubbin $(1959,1963)$. The blocking effect of ganglioplegics on $\beta$-adrenergic vasodilator receptors was demonstrated by Shimamoto et al. (1955).

The increased pressor response in the rats treated with chlorpromazine-pentobarbital may be explained by the $\alpha$-adrenergic blocking effect (Supek et al., 1962; Gokhale et al., 1964) and the potent inhibition of the central nervous system which occur in rats treated with these two agents in combination.

It is of interest that atropine pretreatment had no effect on HR and also did not affect the Octapressin-induced decrease in HR. Propranolol pretreatment caused a considerable decrease in HR and prevented the Octapressin-induced decrease in HR. These observations are consonant with dominant sympathetic control of HR in the rat (Krieger, 1964). A recent study (Robinson et al., 1966) on the control of HR by the autonomic nervous system revealed that in man during exercise, alterations in HR are largely the result of variations in sympathetic activity. The dissociation of the vasomotor-reflex and the reflex bradycardia, as occurring in atropine-treated rats, has been reported previously (Winder, 1937; Heymans et al., 1956).

Elevation of peripheral resistance of the systemic circulation is frequently accompanied by changes in CO (Beznák, 1958; Guyton et al., 1959). In the present experiments, Octapressin had no effect on $\mathrm{CO}$, although a considerable increase in vascular resistance occurred. An additional stimulating effect of Octapressin on myocardial contractility may play a role in maintaining a constant $\mathrm{CO}$, with the heart pumping against an increased peripheral resistance. However, the technique used does not permit to draw a conclusion in this respect. It is suggested that this peptide in the dose-range used here may serve for studying heart function under conditions in which the heart performs against an elevated peripheral resistance, but without a change in $\mathrm{CO}$.

\section{ACKNOWLEDGEMENTS}

We gratefully acknowledge the generous supply of Octapressin (Sandoz Ltd., Basle, Switzerland) and of phenoxybenzamine (dibenzyline, Smith, Kline and French Laboratories Ltd., Welwyn Garden City, Herts, England, by courtesy of R.I.T. Ltd., Den Haag, The Netherlands).

The authors are indebted to Mr. J. J. Alflen for preparing the thermistor catheters.

\section{REFERENCES}

Berde, B., H. Weidmann and A. Cerletti, 1961, Ueber Phenylalanin ${ }^{2}$-Lysin-Vasopressin, Helv. Physiol. Pharmacol. Acta 19, 285.

Beznak, M., 1958, Cardiac output in rats during the development of cardiac hypertrophy, Circulation Res. 6, 207.

Beznak, M., 1959, Hemodynamic changes in hypophysectomized rats, Circulation Res. 7, 907.

Boissonnas, R. A. and St. Guttmann, 1960, Synthèse d'analogues de l'oxytocine et de la lysine-vasopressine contenant de la phenylalanine ou de la tyrosine en positions 2 et 3, Helv. Chim. Acta 43, 190.

Bollobás, B., 1963, Experimentelle Untersuchungen zur Wirkung von Octapressin auf operative Agressionen, Wien. Med. Wschr. 113, 275.

Crawford, R.A.D., 1965, Preliminary trial of a new haemostatic; octapressin-Sandoz, Brit. J. Ophthal. $49,49$.

Dekanski, J., 1952, The quantitative assay of vasopressin, Brit. J. Pharmacol. 7, 567. 
Fegler, G., 1957, The reliability of the thermodilution method for determination of the cardiac output and the blood flow in central veins, Quart. J. Exper. Physiol. 42, 254.

Feruglio, F.S., F. Greco, L. Cesano, D. Indovina, G. Sardi and L. Chiandussi, 1964, Effect of drug infusion on the systemic splanchnic circulation: II. Octapressin infusion in normal and cirrhotic subjects, Clin. Sci. 26, 493.

Gardier, R.W., A. B. Richards, E. A. James Jr. and J.E. Wheeler, 1965, Vasopressin vasodynamics: I. The pharmacology of tachyphylaxis, Arch. Int. Pharmacodyn. 153, 232.

Gokhale, S. D., O. D. Gulati and H. M. Parikh, 1964, An investigation of the adrenergic blocking action of chlorpromazine, Brit. J. Pharmacol. 23. 508.

Goldman, H., 1965-1966, Vasopressin modulation of the distribution of blood flow in the unanesthetized rat, Neuroendocrinology 1, 23.

Guyton, A.C., B. Abernathy, J. B. Langston, B. N. Kaufmann and H.M. Fairchild, 1959, Relative importance of venous and arterial resistance in controlling venous return and cardiac output, Am. J. Physiol. 196, 1008.

Haas, E. and H. Goldblati, 1959, Effects of an antihypertensive drug, pentolinium, Am. J. Physiol. 196,763 .

Heymans, C., A. F. De Schaepdryver and T. O. King, 1956, Carotid sinus baroreceptors and adrenaline hypertension, Arch. Int. Pharmacodyn. 107, 479.

Heymans, C. and E. Neil, 1958, Reflexogenic areas of the cardiovascular system (J. and A. Churchill Ltd., London) pp. 19-89.

Krieger, E.M., 1964, Neurogenic hypertension in the rat, Circulation Res. 15, 511.

Longo, L. D., J.A. Morris, R.W. Smith, R. Beck and N.S. Assali, 1964, Hemodynamic and renal effects of octapressin, Proc. Soc. Exp. Biol. (N.Y.) 115, 766.

Lum, B.K. B. and P. L. Rashleigh, 1961, Potentiation of vasoactive drugs by ganglionic blocking agents, J. Pharmacol. Exp. Ther. 132, 13.

Mantegazza, P., C. Tyler and E.Zaimis, 1958, The peripheral action of hexamethonium and of pentolinium, Brit. J. Pharmacol. 13, 480.

Maxwell, G. M., 1965, The cardiovascular effects of octapressin, Arch. Int. Pharmacodyn. 158, 17.

Nash, C. B., 1965, Alteration of vasopressin tachyphylaxis by reserpine pretreatment, Arch. Int. Pharmacodyn. 155, 90.

Nielsen, A.T., 1965, On the antidiuretic activity of phe ${ }^{2}$-lys ${ }^{8}$-vasopressin in the rat, Acta Endocr. (Kbh.) 49, 312.

Page, I. H., 1949, Pathogenesis of arterial hypertension, J. Am. Med. Ass. 140, 451.

Page, I. H. and J.W. McCubbin, 1959, Buffer reflexes, tolerance to ganglioplegics and their relationship to enhanced pressor responsiveness, Am. J. Physiol. $197,217$.
Page, I. H. and J.W. McCubbin, 1963, Mechanism by which ganglioplegics and atropine enhance cardiovascular responsiveness, Am. J. Physiol. 205, 1.

Page, I. H. and J.W. McCubbin, 1965, Autonomic regulation of arterial pressure responses, Arch. Int. Pharmacodyn. 157, 152.

Page, I. H. and F.Olmsted, 1963, Hemodynamic mechanisms of increased cardiovascular response resulting from ganglioplegies and atropine, Am. J. Physiol. 204, 582 .

Page, I. H. and R. D. Taylor, 1950, Augmentation of vasoactive substances by tetraethylammonium chloride, Circulation 1, 1233.

Prado, J. L. and E. A. Carlini, 1959, Influence of tetraethylammonium, pentolinium and hexamethonium on the action of hypertensin, Arch. Int. Pharmacodyn. $122,100$.

Ribot, S., S. Abramowitz, W. S. Kelhoffer, H. Green, M. J.Small and I. Schwartz, 1963, Cardiovascular effects of phenylalanyl- 2 lysyl- 8 vasopressin (PLV-2), Am. J. Med. Sei. 246, 479.

Richardson, A.W., T. Cooper and T.Pinakatt, 1962 , Thermodilution method for measuring cardiac output of rats by using a transistor bridge, Science $135,317$.

Robinson, B. F., S.E.Epstein, G.D. Beiser and E. Braunwald, 1966, Control of heart rate by the autonomic nervous system, Circulation Res. 19, 400.

Romano, M. N. and L. B. Hinshaw, 1965, Influence of phenoxybenzamine on vascular responses to vasoactive agents, Proc. Soc. Exp. Biol. (N.Y.) 120, 432.

Rosas, R., D. Montague, M. Gross and D. F. Bohr, 1965 , Cardiac action of vasoactive polypeptides in the rat, Circulation Res. 16, 150.

Segel, N., 1964, The circulatory effects of synthetic vasopressin in cirrhosis of the liver, Am. Heart $J$. $67,846$.

Shimamoto, K., O. Kanauchi and S. Uchizumi, 1955, Peripheral action of the ganglion blocking agents, Japan. J. Pharmacol. 5, 66.

Supek, Z., B. Uroic, V. Gjuris and N. Maryan, 1962, The effect of adrenergic blocking agents and of chlorpromazine on blood pressure increase by vasopressin and angiotensin, J. Pharm. Pharmacol. $14,284$.

Tsakiris, A., U. P. Haemmerli and A. Bühlmann, 1964, Reduction of portal venous pressure in cirrhotic patients with bleeding from oesophageal varices, by administration of a vasopressin derivative, phenylalanine 2 -lysine 8 -vasopressin, Am. J. Med. 36, 825.

Wagner, H.N. and E. Braunwald, 1956, The pressor effect of the antidiuretic principle of the posterior pituitary in orthostatic hypotension, J. Clin. Invest. 35,1412 .

Wakim, K. G., C. Denton and H.E.Essex, 1954, Certain cardiovascular effects of vasopressin (pitressin), Am. Heart J. 47, 77.

Wilcoxon, F., 1945, Individual comparison by ranking methods, Biometries 1, 80.

Winder, C.V., 1937, Pressoreceptor reflexes from the carotid sinus, Am. J. Physiol. 118, 379. 